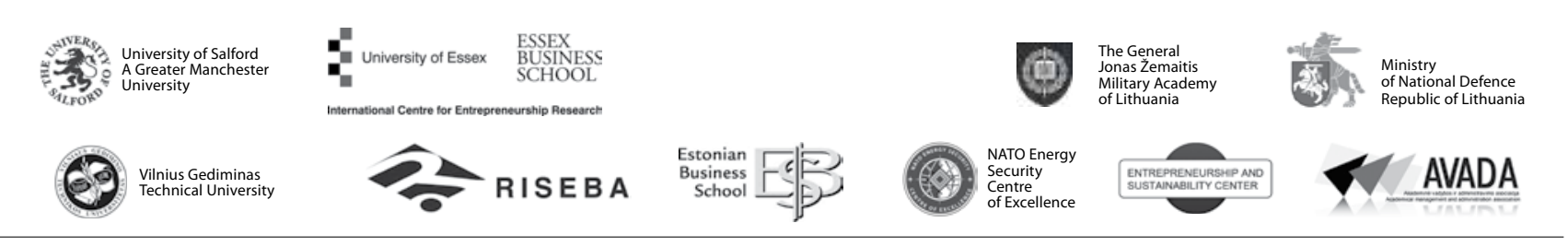

\author{
JOURNAL OF SECURITY AND SUSTAINABILITY ISSUES \\ ISSN 2029-7017 print/ISSN 2029-7025 online \\ 2018 June Volume 7 Number 4 \\ https://doi.org/10.9770/jssi.2018.7.4(10)
}

\title{
REGIONAL RISKS AND CHALLENGES IN SMART GROWTH IN LATGALE REGION (LATVIA)
}

\section{Ludmila Aleksejeva $^{1}$, Viktorija Šipilova², Elita Jermolajeva ${ }^{3}$, Inta Ostrovska ${ }^{4}$, Dmitrijs Oḷehnovičs 5}

\author{
${ }^{1}$ Daugavpils University, Department of Economics and Sociology, Parādes street 1, Daugavpils, Latvia \\ ${ }^{2,4}$ Daugavpils University, The Institute of Humanities and Social Sciences, Parādes street 1, Daugavpils, Latvia \\ ${ }^{5}$ Daugavpils University, Department of History, Vienības street 13, Daugavpils, Latvia \\ ${ }^{3}$ Latvia University of Agriculture, Institute of Business and Management Science, Svētes street 18, Jelgava, Latvia

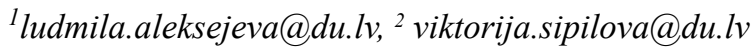

10 February 2018; 15 June 2018

\begin{abstract}
Rural areas are particularly important for ensuring sustainability and smart development of a state as a whole. The present study reflects the quantitative and qualitative assessment of smart growth challenges in the region of Latgale (Latvia) at the level of 19 districts. Worked out within the framework of the Latvian National Research Programme EKOSOC-LV, the present study focuses on smart growth as a tool for risk prevention and the use of opportunities in regional development within the framework of the concept of smart specialization. The research aim is to estimate the risk factors that influence the formation of a smart territory and to analyse the interrelationship of quantitative indicators and expert opinions. By analysing the theoretical principles, the regional actors' recommendations, taking into account the research group participants' and regional experts' findings, the authors characterize the processes and the risks of smart development, as well as make assumptions about the development of the desired situation. The significant risk in the development of Latgale region is the decline in its population. At the same time, the results of the research show that the population is the most important cornerstone of smart growth of the rural territories in Latgale region. Both the objective data processing (statistical analysis) and the subjective point of view (the results of the expert survey) highlight a number of significant risk factors for promoting smart regional space and the growth of knowledge-based economy: the insufficient development of the population's economic activity particularly in the knowledge-based segment, and the small population size. The assessment of various challenges and risks in the regional development of Latvia, as well as the integrated application of quantitative and qualitative approaches allows for the elaboration of a comprehensive vision of the smart growth processes in Latgale region of Latvia. The quantitative assessment is based on the establishment and testing of the integrated index (Smart Development Index). The qualitative assessment is based on the regional experts' opinions summarized by using the Analytic Hierarchy Process methodology. The research results have both scientific and practical applicability in promoting smart development in rural areas. First of all, the results of the study offer a possible methodological solution for the assessment of smart development. Secondly, the obtained scientific experience can be used for solving practical problems at the level of the districts of Latgale region.
\end{abstract}

Keywords: Latgale region (Latvia), regional development, smart specialization, knowledge-based segment, Smart Development Index

Reference to this paper should be made as follows: Aleksejeva, L.; Šipilova, V.; Jermolajeva, E.; Ostrovska, I.; Oḷehnovičs, D. 2018. Regional risks and challenges in smart growth in Latgale region (Latvia), Journal of Security and Sustainability Issues 7(4): 727-739. https://doi.org/10.9770/jssi.2018.7.4(10)

JEL Classifications: R11, O18

\section{Introduction and theoretical background}

Improvements in regional prosperity within the framework of the new paradigm of regional development should be linked to strengthening the competitiveness of the territories through their potential, i.e. resources, social 
capital, technologies, effective governance, institutional capacity, and the correct emphases in development, which form a major challenge for each region (e.g., McCann, Rodriguez-Pose 2011; Vanthillo, Verhetsel 2012; Koumparou 2013; Naldi et al. 2015; Aleksejeva 2016; Komarova et al. 2018; Iorio et al. 2018; Tvaronavičiené et al.; Fomina et al. 2018). The Smart Development Index, which includes all the dimensions necessary for the development of a region (resources, population, economy and governance), allows for the identification of new trends in the development of Latgale region.

Thus, the potential solution to the introduction of smart specialization in small rural areas can be found using a place-based regional approach, which envisages realizing the potential of each territory (e.g., McCann, Rodriguez-Pose 2011). Basing on the scientific literature, the authors of the research emphasize the need to use the potential of any territory (e.g. Vanthillo, Verhetsel 2012) and the possibilities for ensuring smart development in distinctly rural areas (Naldi et al. 2015), which also enlarge the opportunities for small rural areas to engage in the process of smart specialization, reducing the risks of sustainable development of these territories. As concluded by Lindqvist et al. (2013) in the study "Implementing the Concept of Smart Specialisation in the Nordic Countries: an Exploratory Desk Study", the policy of introducing and implementing smart specialization in Northern Europe depends on the type, the potential and the impact of the regions. However, Lindqvist et al. (2013) indicate, that there exist also common "success factors", for example, the analysis of "critical mass" activity and interdisciplinary, cross-sectoral cooperation and partnership between regions at local, national and global levels, in developing and implementing innovation strategies and policies.

Since the paradigm of smart growth is new for Latvia and its regions, possibilities of small districts are limited not only due to their socio-economic capabilities, but also due to the lack of available examples, knowledge and experience in this area. However, this problem is topical not only for Latvia (Šipilova et al. 2017a). According to the OECD (2013) research "Innovation-Driven Growth in Regions: the Role of Smart Specialisation", smart specialization is:

- the focus on the comparative advantages of scientific, technological and economic specialization;

- policy intelligence in order to identify the areas that already have or might develop comparative advantages in future;

- ensuring the orderliness of governance in order to bring together the potential of all involved parties in a specialization strategy (OECD 2013).

Examples of individual countries that, according to their regional development goals and start-up positions, are similar to Latvia (e.g., Lithuania, Romania) show an aspiration towards uniqueness and smartness in regional development (see, for instance, Gedminaite-Raudone 2014; Talmaciu 2012). The authors of the study apply several scientific methods for detecting the key risks and factors driving regional growth in small districts in Latgale in the framework of a place-based approach. The new paradigm of regional development policy envisages the use of the place-based or context-specific approach in the process of evaluating and promoting the development (Ostrovska et al. 2016). This approach emphasizes Europe's rich territorial diversity, encouraging the use of this factor to promote the development of territories (ESPON 2013). The approach envisages that strengthening of the competitiveness of an area is based on identifying the context and the values of a particular place, community or region.

During the process of evaluating and promoting the development of territories it is necessary to focus on targeted and sustainable use of local territorial resources, approaches and technologies applied in the use of resources, specifics of governance, institutional capacity, know-how, territorial development potential, and other means and growth-enhancing conditions for promoting prosperity. 


\section{Regional Development in Latvia}

\subsection{Characteristics of Latgale region}

The territory of Latgale region is 14,5 thousand $\mathrm{km}^{2}$ (22.5\% of the country's total area); it is located in the eastern part of Latvia and within the country it borders with Zemgale and Vidzeme regions, but in the south - with the Republic of Lithuania (57 km long border). In its turn, $253.2 \mathrm{~km}$ is the EU's external border, including 166.2 $\mathrm{km}$ in the east - with the Russian Federation and $87 \mathrm{~km}$ in the south-east - with Belarus. There are 21 districts in Latgale region, including two republican cities - Daugavpils and Rēzekne, as well as 19 districts. 10 out of 19 districts border with other countries, and the border of nine regions make part of the EU's eastern border six border with the Russian Federation, three - with Belarus (see Figure 1). This is an important challenge for territorial development, because the possibilities for cooperation between border regions are not promoted and are significantly affected by geopolitical initiatives (e.g., sanctions, restrictions on movement, etc.), the different nature of economic activities, the level of development, and other socio-economic peculiarities.

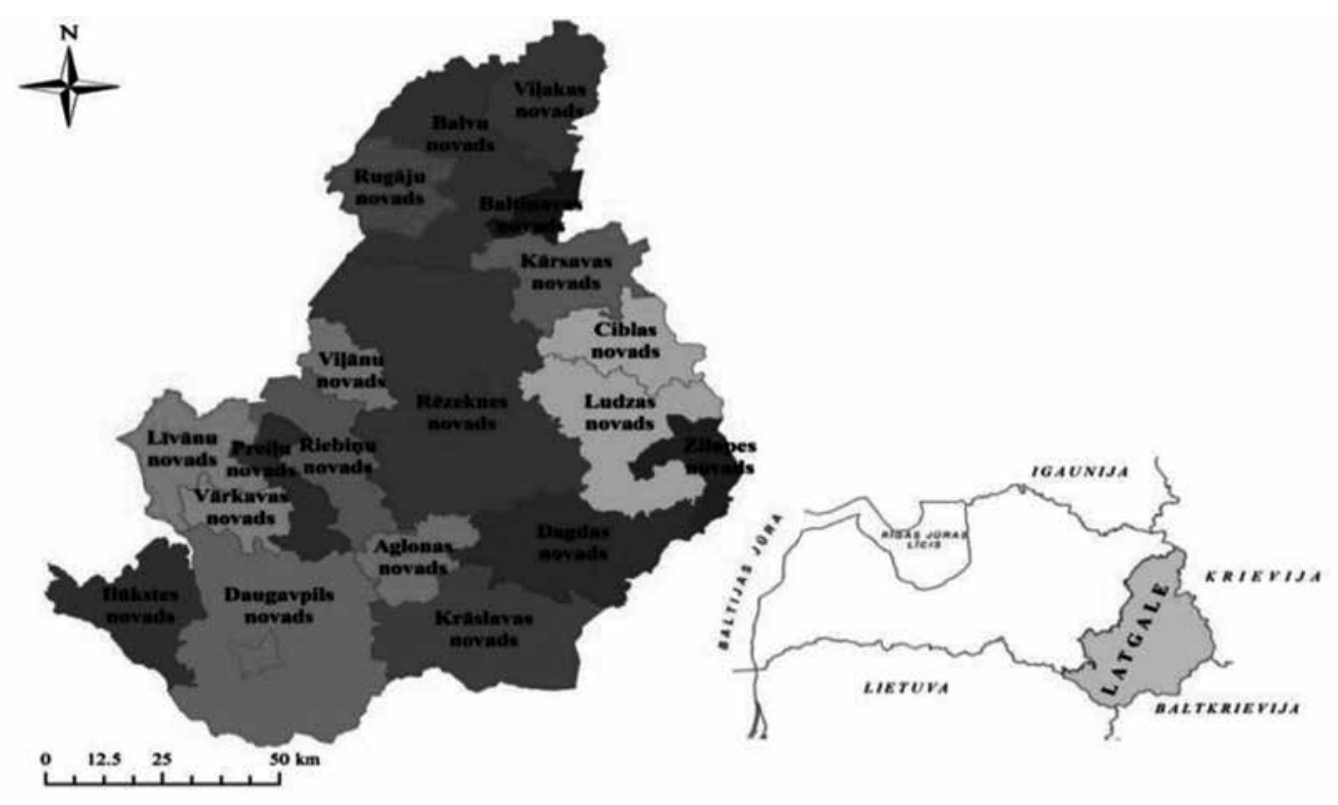

Fig. 1. Map: administrative division of Latgale region

Agriculture, food industry, forestry, wood processing, tourism, metalworking, mechanical engineering, transport, communications and logistics can be considered traditional sectors of Latgale region. Relatively new and promising industries are also developing; thus, renewable energy and energy efficiency, largely based on the sectors of agriculture and forestry, as well as creative industries, health services and health promotion services are growing progressively.

\subsection{Research Results and Discussion in Latgale Region}

According to the modern paradigm of regional development, one of the most essential driving forces of development is man. However, the regions of Latvia face a major challenge - the decrease in the number of its inhabitants. According to the data of the Central Statistical Bureau, the number of Latgale inhabitants has continued to decrease in recent years and at the beginning of 2017 was 270.2 thousand or $13.9 \%$ of the total population of the country, but the population density was 18.6 inhabitants $/ \mathrm{km}^{2}$ (CSP 2017).

The distribution of Latgale districts according to the population shows that relatively highly-populated areas are capable of reaching the above average or high rate of development. In contrast, sparsely populated areas show a stagnation trend. (Jermolajeva et al. 2017). It has to be concluded that the largest number of districts (11 out of 19) belong to the group of sparsely populated districts, i.e., the population does not exceed 7682 people. 
In addition, the majority of districts - 12 out of 19 - are predominantly rural areas (more than $50 \%$ are rural inhabitants) according to the proportion of rural population (more than $50 \%$ are rural people); moreover, in the outermost, as well as in predominantly rural areas, the more rapid trend of population aging is observed. This is to be considered a risk to the development of the region and therefore it is important to understand the peculiarities of the "stagnant" and "fast growing" rural areas and to identify the potential drivers of their growth.

Notwithstanding the relatively small size of population, a high level or a high rate of growth has been observed in several districts of Latgale region. This testifies to the fact that even with low population density, the measures promoting the development of the districts are being implemented, which allows a particular region to increase its growth rate. Several districts are "retreating territories", i.e. they have exhausted the possibilities of increasing their growth rates. Therefore, it would be important for these districts to find new resources, means, and opportunities for smart growth so that to ensure future development and increase growth rate at a new level of development.

The average values of the Smart Development Index show that the level of smart growth in Latgale region is comparable to that of other regions. For example, Kurzeme region and Zemgale region demonstrate average values of Smart Development Index close to those of Latgale region (Šipilova et al. 2017b).

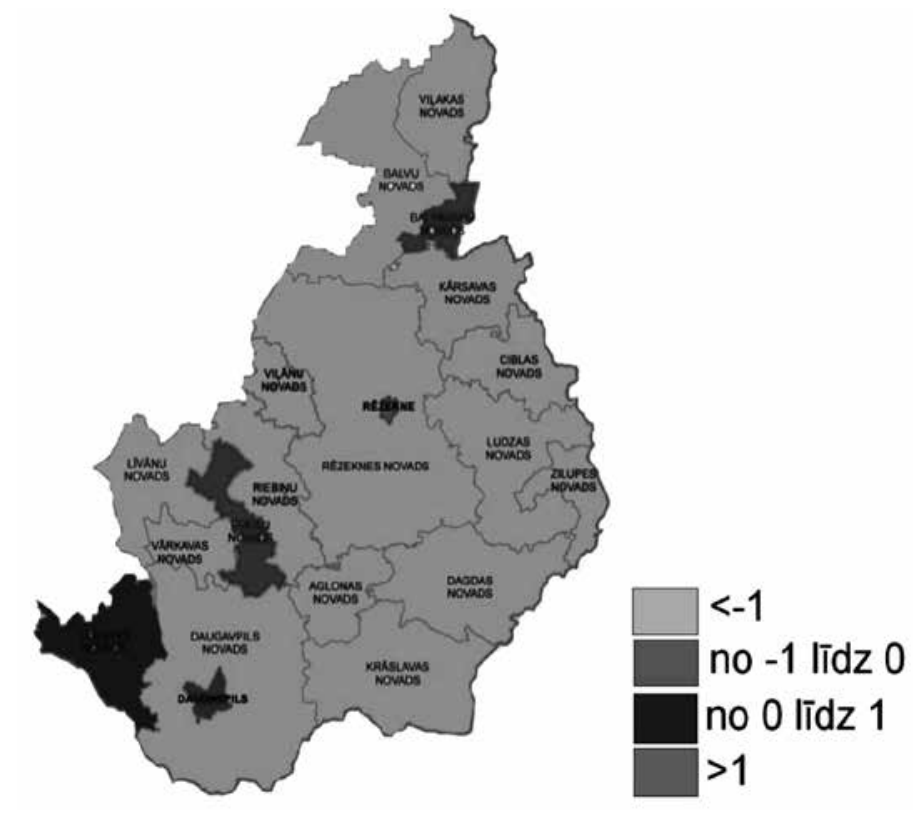

Fig. 2. Smart Development Index in Latgale districts

Source: EKOSOC-LV data

The maximum values of the Smart Development Index indicate that clearly unfavourable development in Latgale region is not observed (see Figure 2). The lowest index value (-10.008) in Latvia is encountered in Skrunda district of Kurzeme region, rather than in Latgale region. The peak index value of 7.386 reached in the district of Ilūkste in Latgale region is not far from the Kurzeme region's maximum index value, which is 10.554 (e.g. Sipilova et al. 2017b). Moreover, it can be concluded that smart growth in Latgale region proceeds more evenly than in other regions, since the difference between the maximum and the minimum index values is smaller than in other regions. However, generally, the values of the Smart Development Index in the districts of Latgale region are relatively low.

The calculation of median values shows that in half of the districts of Latgale region, the Smart Development Index does not reach the value of 0.43 , and this value is about 2.5 times lower than the index average of 1.074. The median value in Latgale region testifies to the fact that in most of the rural areas of the region, smart growth is significantly delayed in comparison with other regions of Latvia (e.g. Šipilova et al. 2017b). 
In Latgale districts, the values of the Smart Development Index reflect the division of districts into two similar groups, where the first group is made up of ten districts with positive values of the index and the second group contains nine districts with negative index values (Jermolajeva et al. 2017). According to RDIM data (RDIM 2015), it is possible to calculate that in the group of districts with positive index values in 2014 there lived $62.31 \%$ of the inhabitants of the districts of Latgale region, which is a trend that is favourable for smart growth. However, in all 10 districts with positive values of the Smart Development Index, the growth rate observed is low or lower than average. Those districts where the growth rate is above average or high (Daugavpils, Vārkava, Cibla and Zilupe districts) belong to the group of districts with negative values of the Smart Development Index.

As a result, it can be concluded that smart growth of all the districts in Latgale region proceeds relatively smoothly, however, the districts with higher levels of smart growth develop more slowly than the regions with lower smart growth levels. However, in order to reduce the outflow of people from the regions to Riga and / or its surrounding districts (as well as to other countries), it would be necessary, alongside with Riga, to increase the other regions' economic importance and attractiveness for doing business and choosing a place of residence (Jermolajeva et al. 2017).

In carrying out the qualitative evaluation of the region's development, the experts were asked about the four dimensions of smart growth and their importance in the development of Latgale region. Four trends were identified: smart governance, smart resources, smart population, and smart economy. The experts evaluated how those factors reflected the formation and development of smart territory in determining the scenario for the growth of the region. When evaluating those trends, the concept based on inhabitants' education, entrepreneurship, creativity, active involvement in the life of the local community (0.37) was emphasized as the most significant for Latgale region, which had a significant preponderance of points (see Figure 3 ).

The obtained results could indicate a vivid reaction to the decrease in the number of population in Latgale region at a time when, according to the new paradigm of regional development, the importance of human capital for the development has been emphasized. It is positive that Latgale is the only region in Latvia where the experts have emphasized the population-centred development scenario. Thus, maintaining the population and the successful use of their potential in the districts and the region is an important factor in ensuring sustainable development (Aleksejeva et.al. 2018, Lavrinenko et al. 2017b).

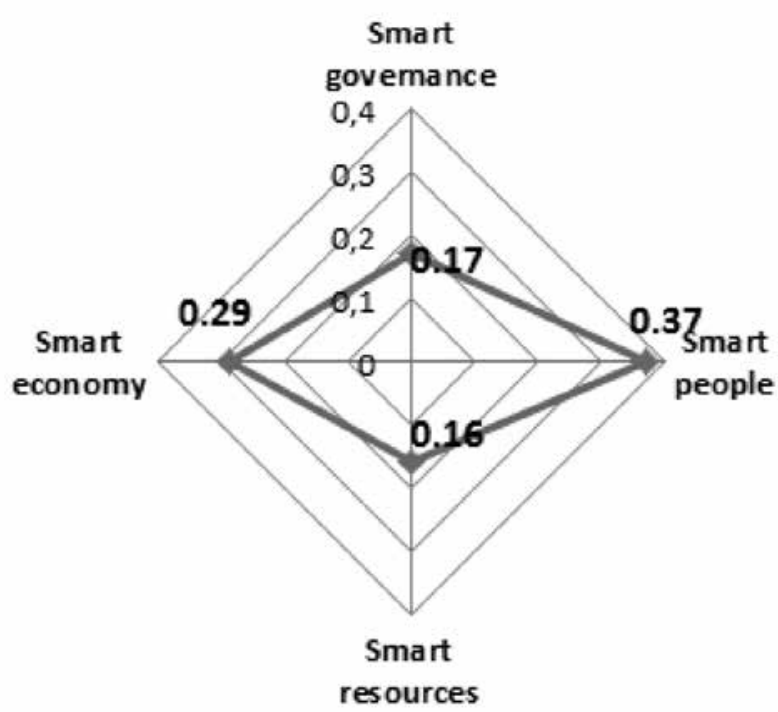

Fig. 3.

a) Importance of the Smart Development Index dimensions from the expert point of view

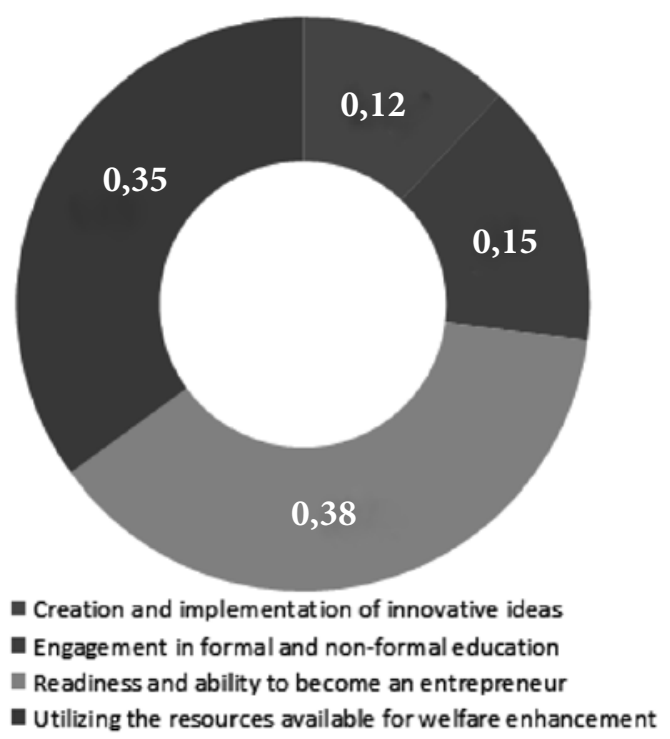

b) The factors affecting the Population Dimension of the Latgale region's smart specialization from the expert viewpoint 
According to the calculated correlation coefficients, the population dimension has a moderate correlation (and a higher correlation coefficient than the other dimensions $r=0.615$ ). Describing the indicators of the region's economic development, it is to be concluded that in Latgale region the growth of entrepreneurship in rural areas is positive, as both the number of new enterprises $(+60.81 \%)$, the number of employees $(+10.73 \%)$, as well as the net turnover $(+51.02 \%)$ are increasing. A positive trend marks also the efficiency of the new entrepreneurship, as the net turnover growth is five times higher than the increase in the number of employees (Šipilova 2017).

The data analysis of entrepreneurship growth allows for emphasizing significant trends. When analysing the growth of entrepreneurship, the authors take into account not only the dynamics in the number of enterprises but also the characteristics of the districts of Latgale region according to the level of development and the growth rate, as well as the number of population.

In order to understand the smart growth trends in rural areas in Latgale region in detail, it is necessary to consider the segment of Knowledge-Based Economy (hereinafter KBE segment), which includes the sectors of high technology and medium-high technology manufacturing industries and knowledge-intensive services. When assessing the growth of the indicators of business activity in the KBE segment, it should be emphasized that predominantly they have been faster than entrepreneurship in general, particularly in the sectors of, high technology and medium-high technology manufacturing industries.

In 2015, the number of knowledge-intensive enterprises in Latgale region totalled 878: 630 - in cities and 248 - in districts, and they employed 8058 employees: in cities - 5884, in the districts -2174 . Thus, the turnover per employee was on average 82.6 thousand EUR: in cities - 108.8 thousand EUR, in the districts -11.8 thousand EUR. When analysing the situation in certain districts (see Fig. 4), it is obvious that in 2015, most of knowledge-intensive enterprises were situated in Līvāni district (35), Daugavpils district (32), and in Preiḷi and Rēzekne districts -30 in each.

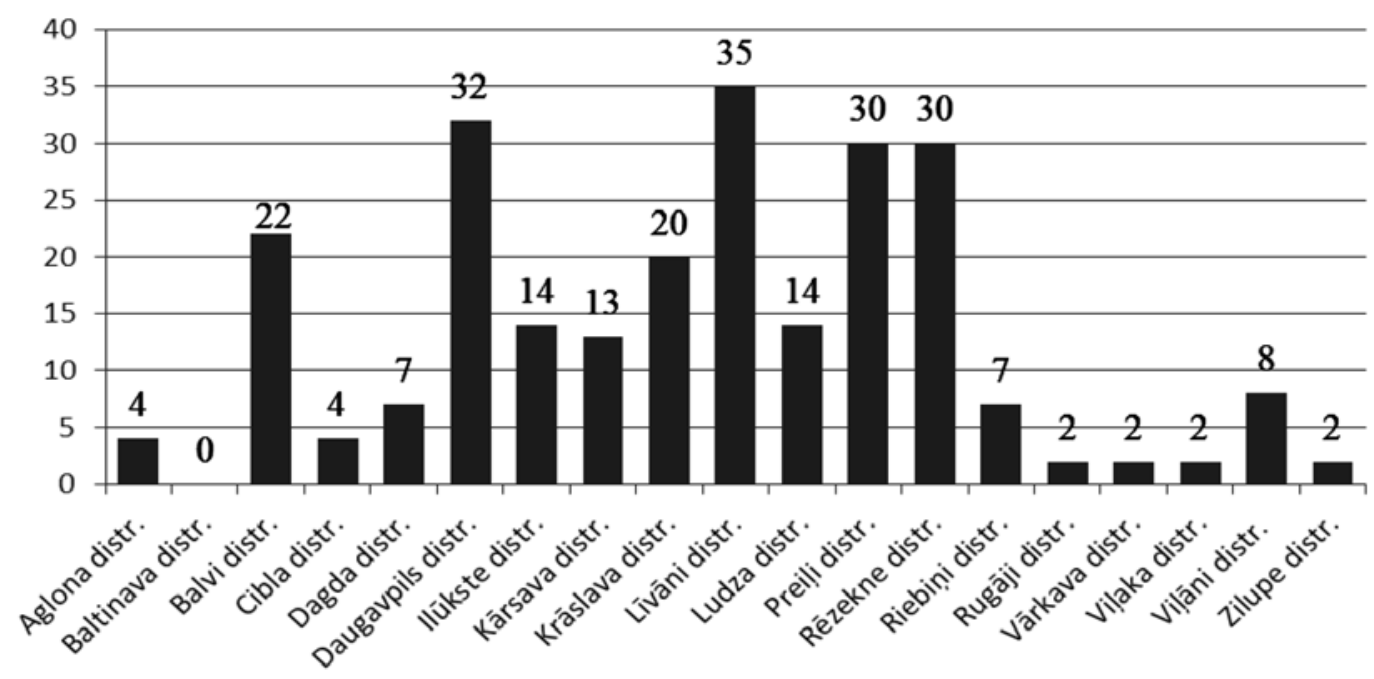

Fig.4. The number of knowledge-intensive enterprises in the districts of Latgale in 2015.

Source: RDIM 2017

In terms of the number of the employed in knowledge-intensive companies, Livañni district was in the $1^{\text {st }}$ place (395 people), too, followed by Balvi district (354), Preiļi district (282) and Krāslava district (277). A positive trend marks also the efficiency of the new entrepreneurship, as the net turnover growth is five times higher than the increase in the number of employees.

According to the data, the districts of Latgale region, taking into account the increase in the number of companies of the $K B E$ segment, can be divided into five groups. The first group consists of the regions with negative 
or zero growth observed (Rugāji, Viḷāni, Baltinava, Zilupe); the second group includes the districts, whose growth is below the average indicator of Latgale region (Aglona, Balvi, Krāslava, Ludza, Lìvāni, Ilūkste), the third group consists of the districts, the growth of which is very close to the average indicator of Latgale region (Daugavpils, Cibla, Dagda, Preiḷi, Vārkava, Viḷaka), the fourth group - the districts where the increase is above the average indicator for Latgale (Rēzekne), and the fifth group includes the regions with a marked increase (Kārsava, Riebinini). As a result, the growth trend of the KBE segment can be considered outstanding only in three districts - Rēzekne, Kārsava, and Riebiņi. Taking into account also the districts' growth rates, it is necessary to emphasize the marked differences between the districts and the modest growth of the KBE segment in the districts with above average or high growth rates compared to the districts with low or medium growth rates.

For example, in the regions with low growth rate and low development level, the growth of the KBE segment $(+162.28 \%)$ almost three times exceeds the indicator of the overall growth of entrepreneurship $(+68.42)$. However, in this group of districts there are also marked differences between the districts according to the growth rates of the KBE segment (e.g., Riebini district $+600.00 \%$, Baltinava district $+0.00 \%$, Viḷāni district $-10.00 \%$ ). The number of districts is considerably smaller in the group of districts with the growth rate above average or high growth rate. Among these districts, only Daugavpils and Cibla districts demonstrate a significant increase in the KBE segment $(+94.44 \%$ and $+100.00 \%$ respectively). In other districts of this group, the growth of the KBE segment has not taken place or occurred to a lesser extent than the increase in entrepreneurship in Latvian economy as a whole.

The trends established allow for the conclusion that rural areas in Latgale region have the potential to develop knowledge-based economy (see Table 1). However, these trends have not yet sufficiently reflected the improvement of the development of the districts - the correlation between the growth of the KBE segment (by the number of enterprises) and the Smart Development Index in Latgale region practically does not exist (see Figure 5).

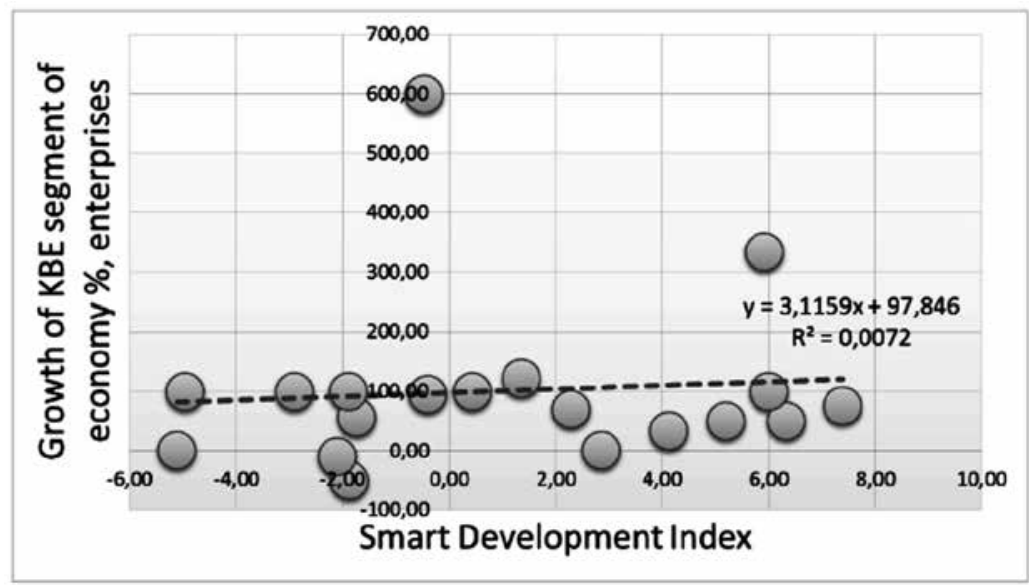

Fig. 5. Correlation between the growth of the KBE segment and the Smart Development Index in Latgale region

Source: developed by the authors using EKOSOC-LV, Lursoft data.

The data presented in Figure 5 show that there is no significant correlation between the growth of the KBE segment and the Smart Development Index. This is a rather logical outcome, notwithstanding the opinion of the experts surveyed by EKOSOC-LV about the high significance of the economic dimension for ensuring smart growth in rural areas in Latgale region, because the relation of this dimension to the Smart Development Index in Latgale region is weak in comparison with other regions.

In addition, this can be explained by the pronounced differences in districts according to the increase in the KBE segment. The second reason is the difference in the population density in the districts, since 11 of the 19 
districts of Latgale region have a small number of population (1112-7686 inhabitants), which affects also the economic performance, because the amount of human resources is limited. Moreover, these 11 districts also have low growth rates (Aleksejeva et al. 2018). The general tendency of business growth shows that the population of Latgale region's rural areas is relatively active in entrepreneurship, and in the KBE segment, despite this, Latgale region still has a high proportion of districts with small numbers of population and low growth rates.

As demonstrated by the quantitative and qualitative analysis carried out in the framework of EKOSOC-LV, there are manifestations of smart growth obvious in Latgale region (e.g., Šipilova et al. 2017b; Aleksejeva et al. 2018; Jermolajeva et al. 2017). Among them, in the context of smart growth, and taking into account the opinion of the surveyed experts about the great importance of the population and the economy in the smartness of the region, it would be necessary to emphasize the trends in business growth in the segment of knowledgebased economy, as well as possible risks that could reduce the positive effect on the total smart growth in the region.

Table 1. SWOT analysis of regional risks in smart growth in small districts in the context of population-based scenario - the case of Latgale region

\begin{tabular}{|l|}
\hline \multicolumn{1}{|c|}{ STRENGTHS } \\
\hline a) business growth in the segment of knowledge-based economy \\
proceeds faster than in other segments of economy \\
b) the proportion of knowledge-intensive segment gradually \\
increases in the structure of the economic activity of the region \\
c) there is an increase in the knowledge-intensive segment \\
observed in the districts with low level of development and small \\
size of population \\
d) experts consider people of the region being the basis for smart \\
growth
\end{tabular}

BUSINESS ACTIVITY IN SEGMENT OF KNOWLEDGE-BASED ECONOMY

\section{WEAKNESSES}

a) the districts are not well-aware of scientific and practical experience in smart growth in small districts

b) local inhabitants leaving for the existing development centres outside Latgale region

c) the concentration of the largest part of the region's population in the districts with low growth rate

d) low business activity in the region

e) low growth rates in the districts with a relatively high level of development

f) weak correlation between the dimension Economy and the Smart Development Index

g) weak correlation between the growth in the knowledge-

intensive economy segment and the Smart Development Index

EXISTING GROWTH TRENDS, WEAK REFLECTION

OF "SMART ACTIVITIES" IN GROWTH, INSUFFICIENT EXPERIENCE IN THE APPLICATION OF THE SMARTNESS CONCEPT

\section{OPPORTUNITIES}

a) less developed regions show a trend towards development b) according to the experts, the greater impact on smart growth in the region can be produced by the dimensions Population and Economics

c) greater involvement of citizens in entrepreneurship d) more effective use of resources for the production of higher added value

$\boldsymbol{e}$ ) engagement in life-long learning, non-formal education f) active use of the EU funds for the realization of the districts' potential

\author{
ACTIVE INVOLVEMENT OF THE POPULATION IN \\ VARIOUS GROWTH PROCESSES WITHIN \\ THE FRAMEWORK OF THE SMARTNESS CONCEPT \\ IN ALL DISTRICTS OF THE REGION
}

\section{THREATS}

a) the lack of methodological solutions for the evaluation of smart growth that are applicable and widely used for small areas

b) the amounts of the collections of statistical data, their periodicity

c) difficulties in correct identification of the potential of a territory and its potential for development

d) in scientific literature small areas are discussed insufficiently e) the confusion of districts as to how to introduce smart growth due to the lack of strong impulses

f) weak development trend in the region in general

g) opportunities to involve all the interested parties

h) resources are mostly used to produce low added value i) the decrease in the number of population at a time when, according to experts, the Population is recognized as the dominant source of smart growth in the region

\section{THE POPULATIONS' IGNORANCE / UNAWARENESS OF THE REGIONS' POTENTIAL AND LEAVING FOR OTHER CENTRES OF DEVELOPMENT}


According to Olaniyi and Reidolf (2015), regional growth is linked to business potential, including in the segment of knowledge-based economy. However, rural areas are usually considered to be less suitable for knowledge-based business, which, according to Olaniyi and Reidolf (2015), is not justified; and the scholars refer to the positive experience of Estonia. Positive examples of the growth of the segment of knowledge-based economy are emphasized also in Latvia (e.g., Rivza et al. 2016; Jermolajeva et al. 2017; Lavrinenko et al. 2017a; Šipilova 2017).

According to the calculations done, the growth of entrepreneurship in the segment of knowledge-based economy in Latgale region has been faster than in the economy in general (e.g. Jermolajeva et al. 2017; Šipilova 2017) as to the number of companies, the number of employees and the net turnover. This undeniably is attributable to the strengths of the region. However, taking into account the peculiarities of this trend in the districts of Latgale region, it is possible to identify both existing and potential risks for the region's smart growth.

At the level of districts in Latgale region, there is a pronounced difference in the growth of business in the segment of knowledge-based economy, and in certain cases there even is the decrease in that growth (e.g., Jermolajeva et al. 2017). The existence of these differences between the districts does not contribute to the smart growth of Latgale region, because the economic capacity of each individual region is limited by the relatively small size of population and the differences in the efficiency of economic activity.

In assessing the ratio between the growth of the employed and the growth of the net turnover in the segment of knowledge-based economy at the level of districts, a common positive trend should be noted. However, in the districts with the indicators of a more rapid growth of entrepreneurship, the number of people employed in the knowledge-based economy has grown faster than the net turnover, which emphasizes the need to increase the efficiency of economic activity.

The region's population and their ability and willingness to become entrepreneurs, according to the experts surveyed by EKOSOC-LV, form the basis for the smartness of Latgale region (e.g., Jermolajeva et al. 2017; Šipilova et al. 2017b). According to the above-mentioned business growth tendencies in the segment of knowledge-based economy, the foundations for the smart growth of Latgale region are provided. However, it is necessary not only to observe the desired trends, but also to see their reflection in the region's smart growth. By analysing the relationship between the growth of the segment of knowledge-based economy and the region's smart growth, it has been clarified that the correlation is weak (e.g., Šipilova 2017), which undoubtedly forms another risk of smart growth of Latgale region. The reason might be the low capacity of new companies. When assessing the data of business growth concerning the number of enterprises and the number of employees in the segment of knowledge-based economy, it can be assumed that in the rural areas of Latgale region those are micro / small enterprises that are established (especially in the sector of knowledge-intensive services), which is an initiative that should be supported especially in rural areas, but their overall contribution to the region's economy is relatively modest. For instance, in the reviewed period (2009-2015), the share of the segment of knowledge-based economy in the region's economy grew by only about $1 \%$, which is ten times lower than in the traditional sectors (agriculture, forestry, fisheries). Despite the positive trend in the growth of the proportion of the segment of knowledge-based economy, since the other sectors (both manufacturing and services) demonstrate a decrease in their proportion, the small trend towards the increase in the proportion of the segment of knowledge-based economy creates a risk of smart growth for the region.

The importance of agriculture, forestry and fisheries continues to significantly increase in the economic activity of Latgale region (e.g., Jermolajeva et al. 2017), which, on the one hand, is positive for the maintenance and development of the traditional economic activity of the region, as well as for the employment of human resources, but on the other hand, according to the authors, it can also be considered a risk for smart growth, since at the moment only a small contribution is made to the smart development of rural areas (for example, through increasing the efficiency of agricultural activities, the development of organic farms) and it would be necessary to continue to actively implement smart solutions in these sectors. 
Positive development of the segment of knowledge-based economy creates favourable grounds and promotes positive trends for promoting smart growth in Latgale region, however, the existing stereotypes about the limited ability of rural areas to be smart in their development poses a risk to the use of existing potential.

For example, the review of scientific and professional literature shows that smartness in processes of development and growth is associated with the creation of new knowledge and technologies, which is unlikely to take place in rural areas (for the literature review see Šipilova et al. 2017a), taking into account their distance from development and knowledge centres and limited human resources (e.g., Steiner, Mossbock 2014); however, studies also show that the existence of educational institutions in rural areas can produce a positive effect on their economic activity (e.g., Šipilova et al. 2016). In general, rural areas have the potential to realize growth and development potential by applying the place-based approach, which emphasizes the importance of the uniqueness of each territory (e.g., McCann, Rodriguez-Pose 2011).

Taking into account the research results, it can be assumed that the main risk for the promotion of smart growth in Latgale region is attributable to the ability to balance the findings arrived at in the result of the quantitative and qualitative assessment that the inhabitants of the region make the basis for smart growth of the region, at a time when the existing tendencies show the low population density of the rural areas and the population's leaving for other development centres. In this context, the potential risk associated with the development of an appropriate growth strategy can also be emphasized, because, as noted by Foray (2014), it is essential to recognize the potential market and governance risks that impede smart specialization. Reducing the negative effects of identified risks on smart growth should be based on the concept of combination of "smart specialization" and the "place-based approach" for successful development of rural areas (for example, Naldi et al. 2015) proposed in the scientific literature.

The existing stereotypes about the ability of rural areas to be smart in their growth and development are rooted in the concept of smartness based on the creation of new knowledge and technologies. These processes are closely related to great financial investments and research activities that are limited in rural areas. Consequently, the experience in the application of the concept of smartness is little developed and the requirements for smart processes in the growth of rural areas are not well understood.

The decrease in the population in Latgale region is an unfavourable trend, because the results of both quantitative and qualitative assessment emphasize the inhabitants of the region as the basis for smart growth and development. Thus, the greatest challenge is to raise awareness among the people of the region about the benefits of smart growth and the potential of the region to promote it. For instance, according to the experts surveyed in the framework of EKOSOC-LV, the strong influence on smart specialization in the region is determined exactly by the population's readiness and ability to become entrepreneurs. The established trends in the segment of knowledge-based economy show that Latgale region has a great potential and it is being applied in the creation of new companies in sectors that promote the smartness of growth.

However, the relatively rapid growth of the segment of knowledge-based economy, which is necessary for the smart growth of Latgale region, is still hindered by inadequate efficacy and pronounced differences at the level of districts, as well as the weak link between this segment and the region's smart growth, as well as the slow increase in the proportion of the segment in the structure of economic activity.

\section{Conclusions}

The most significant issue in regional development that is characteristic to the whole territory of Latvia is the significant differences in the level of socioeconomic development both between regions at the national level and between the districts not only within the country, but also within a specific region. In Latgale region there is a pronounced regional inequality, and the Smart Development Index in Latgale districts reflects their division into two similar groups, where the first group contains ten districts with positive index values and the second group includes nine districts with negative index values. As a result, it can be concluded that in Latgale region 
there is a relatively smooth smart growth between the districts of the region, however, the districts with higher levels of smart growth develop more slowly than the regions with lower levels of smart growth.

At the same time, the experts have acknowledged that citizens' initiatives and activities play an important role in ensuring the region's smart specialization, as attracting and retaining inhabitants and successful exploitation of their potential in the districts and the region as a whole are important factors in ensuring sustainable development.

Despite the issue of depopulation, the increase in entrepreneurial activity is evident exactly owing to the population's activity, smart governance and knowledge-based business potential.

As a result of the analysis, the risks for smart growth of Latgale region can be attributed to:

- available scientific and practical experience on the application of the concept of smartness in rural areas,

- changes in the number of population in the region;

- the development trends in the segment of knowledge-based economy.

Notwithstanding the relatively rapid development of high and medium-high technology sectors, as well as knowledge-intensive service sectors in the rural areas of Latgale region, the economic restructuring in the region continues to be beneficial to traditional industries. In Latgale region, it is necessary to strengthen the links between economy and smart growth, to ensure efficient production with high added value. Increasing productivity in the context of smart growth would be particularly necessary in the sectors of high and mediumtechnologies and in the sectors of knowledge-intensive services.

The quantitative and qualitative indicators make it possible to assess the process of sustainable development in the economically less developed region of Latvia, namely, Latgale. The biggest challenge is related to the loss of social capital and the slow trends of business development. Given that $84 \%$ of the districts have small size of population and a low growth rate, ensuring sustainable development is both a necessity and a challenge.

\section{Acknowledgements}

Publication has been developed in the framework of the National Research Programme 5.2 "Economic transformation, smart growth, governance and legal framework for sustainable development of the state and society - a new approach to the creation of a sustainable learning community" (EKOSOC-LV).
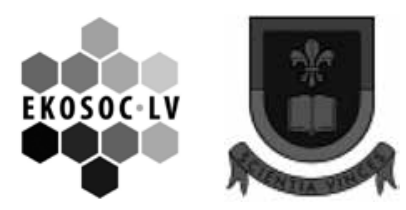

\section{References}

Aleksejeva L., Šipilova V., Ostrovska I., Jermolajeva E., Oḷehnovičs D. 2018. Smart growth in Latgale region of Latvia: an overview of multiple-helix actors. Proceedings of the 8 th International Scientific Conference Rural Development 2017. (ISSN 1822-3230 eISSN 2345-0916 eISBN 978-609-449-128-3) [http://conf.rd.asu.lt/index.php/rd/article/view/565/314]

Aleksejeva L. 2016. Country's Competitiveness and Sustainability: Higher Education Impact. Journal of Security and Sustainability Issues.Vol. 5(3), pp. 355-363 Lithuania. [http://jssidoi.org/jssi/papers/papers/journal/19]

CSP [Data of Central Statisticsal Bureu of Latvia]. Retrieved during the June-August 2017, from http://data.csb.gov.lv

Fomina, A. V.; Berduygina, O. N.; Shatsky, A. A. 2018. Industrial cooperation and its influence on sustainable economic growth, Entrepreneurship and Sustainability Issues 5(3): 467-479. https://doi.org/10.9770/jesi.2018.5.3(4)

Foray D. 2014. From smart specialisation to smart specialisation policy. European Journal of Innovation Management, Volume 17, Issue 4, pp. 492-507. https://doi.org/10.1108/EJIM-09-2014-0096 
Gedminaite-Raudone Z. 2014. Economic assessment of uniqueness of the regions in the context of the European Union. Procedia - Social and Behavioral Sciences, 110 (2014), pp. 259 - 266. http://doi.org/10.1016/j.sbspro.2013.12.869

ESPON 2013. ATTREG The Attractiveness of European regions and cities for residents and visitors. https://www.espon.eu/programme/ projects/espon-2013/applied-research/attreg-attractiveness-european-regions-and-cities

Iorio, M.; Monni, S.; Brollo, B. 2018. The Brazilian Amazon: a resource curse or renewed colonialism?, Entrepreneurship and Sustainability Issues 5(3): 438-451. https://doi.org/10.9770/jesi.2018.5.3(2)

Jermolajeva E., Rivža B., Aleksejeva L., Šipilova V., Ostrovska I. 2017. Smart Growth as a Tool for Regional Convergence: Evidence from Latgale Region of Latvia. Economics and Sociology, 10(4), pp. 203-224. doi:10.14254/2071-789X.2017/10-4/16

Komarova, V.; Lonska, J.; Lavrinenko, O.; Menshikov, V. 2018. Influence of existing social and economic interactions on sustainable territory development: the case of Iceland, Entrepreneurship and Sustainability Issues 5(3): 412-437. https://doi.org/10.9770/ jesi.2018.5.3(1)

Koumparou D. 2013. The Role of Natural Resources and the Social Capital in EU's Growth Strategy - Europe 2020. Edited by: Lekkas, TD. Proceedings of the 13th International Conference on Environmental Science and Technology. [http://apps.webofknowledge.com/ full_record.do?product=WOS\&search_mode=GeneralSearch\&qid=4\&SID=V1Xgpu7jfuCitdgmTZD\&page=1\&doc=1].

Latgales plānošanas regions. 2010a Latgales attīstības stratēgija 2030. Available: http://www.latgale.lv/lv/padome/planosana

Latgales plānošanas regions. 2010b Latgales plānošanas reǵiona attīstības programma 2010-2017. Esošās situācijas analīze. Available: http://www.latgale.lv/lv/padome/planosana

McCann P., Rodriguez-Pose A. 2011. Why and When Development Policy Should Be Place-Based? OECD Observer, 14. 2011: Building Resilient Regions for Stronger Economies, 203-213.

Lavrinenko, O.; Ohotina, A.; Amosova, J.; Teivāns-Treinovskis, J. 2017a. Intercompany networks of the cross-border region (LatviaLithuania-Belarus), Journal of Security and Sustainability Issues 7(1): 39-54. https://doi.org/10.9770/jssi.2017.7.1(4)

Lavrinenko, O.; Jefimovs, N.; Teivāns-Treinovskis, J. 2017b. Issues in the area of secure development: trust as an innovative system's economic growth factor of border regions (Latvia-Lithuania-Belarus), Journal of Security and Sustainability Issues 6(3): 435-444. https://doi.org/10.9770/jssi.2017.6.3(9)

Lindqvist M., Smed Olsen L., Perjo och Haukur Claessen L. 2013. Implementing the Concept of Smart Specialisation in the Nordic Countries: An Exploratory Desk Study. NORDREGIO WORKING PAPER 2013:1

Naldi L., Nilsson P., Westlund H., Wixe S. 2015. What is smart rural development? Journal of Rural Studies, 40, 90-101. doi: http:// doi.org/10.1016/j.jrurstud.2015.06.006

OECD 2013. Innovation - driven growth in regions: the role of smart specialisation. https://www.oecd.org/innovation/inno/smart-specialization.pdf

Olaniyi E., Reidolf M. 2015. Organisational innovation strategies in the context of smart specialization. Journal of Security and Sustainability Issues, 5(2), pp. 213-227. https://doi.org/10.9770/jssi.2015.5.2(7)

Ostrovska I., Šipilova V., Aleksejeva L., Jermolajeva E., Oḷehnovičs D. 2016. Mūsdienu reǵionālās attīstības paradigmas īpatnības: ārvalstu zinātniskās pieredzes apkopojums. Starptautiskās zinātniskās konferences "Sociālās zinātnes regionālajai attīstībai 2015" materiāli (2015. gada 16.-17. oktobris) I daļa. Sociologijas aktualitātes. Daugavpils Universitātes akadēmiskais apgāds "Saule” 2016, pp. 55.- 75 .

Regional development indicators module of Spatial Development Planning Indormation Sistem RDIM 2017. Data tabeles [on-line] Available: http://raim.gov.lv

Rivza B., Kruzmetra M., Zaluksne V. 2016. Performance trends for smart growth in the rural territories of Latvia. Agronomy Research, Volume 14, Issue 5, pp. 1684-1693.

Steiner M., Mossbock J. 2014. How “Smart” are Rural Areas? A Case Study Approach. RSA Winter Conference 2014, November 27-28 2014, London, UK. Available: http://www.regionalstudies.org/uploads/funding/conferences/presentations/winter_2014_presentations_/ michael_steiner_and_johannes_mossb\%c3\%b6ck.pdf

Šipilova V. 2017. Knowledge-based entrepreneurship and smart development in small municipalities: the experience of Latgale region (Latvia). SEA 13 - International Conference on Economic Experiences, Transilvania University of Brasov, Faculty of Economic Sciences and Business Administration, Brasov, Romania, 17 th $-18^{\text {th }}$ November, 2017. Available: http://seaopenresearch.eu/Document/ 
Poster/SEA\%2013\%20Poster\%20Viktorija\%20Sipilova.pdf

Šipilova V., Jermolajeva E., Ostrovska I., Aleksejeva L., Oḷehnovičs D. 2016. Assessing presence of institutions of vocational education as factor contributing to economic activity in small municipalities. Turkish Online Journal of Educational Technology (TOJET), Special Issue for INTE 2016, November 2016, pp. 326-335.

Šipilova V., Ostrovska I., Aleksejeva L., Jermolajeva E., Ol̦ehnovičs D. 2017a A Review of the Literature on Smart Development: Lessons for Small Municipalities. International Journal of Economics and Financial, Issues, 2017, 7(1), pp. 460-469.

Šipilova V., Ostrovska I., Jermolajeva E., Aleksejeva L., Oḷehnovičs D. 2017b Evaluation of Sustainable Development in Rural Territories in Latgale Region (Latvia) by Using the Conception of Smart Specialization. Journal of Teacher Education for Sustainability, Vol. 19, Issue 1 (Jun2017), pp. 82-105. DOI: https://doi.org/10.1515/jtes-2017-0006

Talmaciu M. 2012. Considerations regarding the development of Romanian regional economies through innovation and entrepreneurship. Procedia Economics and Finance, 3 (2012), pp. 914 - 920. https://doi.org/10.1016/S2212-5671(12)00250-X

Tvaronavičienè et al.

Vanthillo, T., Verhetsel, A. 2012. Paradigm change in regional policy: Towards smart specialisation? Lessons from Flanders (Belgium). Belgeo, 1-2 (2012), Inaugural Issue. https://belgeo.revues.org/pdf/7083

Short biographical note about the contributors at the end of the article (name, surname, academic title and scientific degree, duties, research interests):

Dr.oec. Ludmila Aleksejeva is the Asistant Professor of Daugavpils University, Latvia. Research interests: entrepreneurship and regional development; innovation and human resources; economic of education; sustainability.

Dr.oec. Viktorija Šipilova is Researcher at the Institute of Humanities and Social Sciences of Daugavpils University, Latvia. Research interests: regional growth and development, structural changes in economy, economic structure, smart specialization, sustainable development.

Dr.oec. Elita Jermolajeva is Leading Researcher at the Institute of Business and Management Science of Latvia University of Agriculture, Latvia. Research interests: regional and sustainable development, smart growth.

Dr.paed. Inta Ostrovska is Docent at the Institute of Humanities and Social Sciences of Daugavpils University, Latvia. Research interests: regional and sustainable development, smart growth.

Mg.hist. Dmitrijs Oḷehnovičs is Lector at the Department of History of Daugavpils University, Latvia. Research interests: regional and sustainable development, smart growth.

Register for an ORCID ID:

https://orcid.org/register 